\title{
Fishing Agricultural Lakes in Zauralia Russia Becomes Progressive
}

\author{
IS Mukhachev* \\ Doctor of Biological Sciences, State Agrarian University of Northern Zauralye, Russia \\ *Corresponding author: IS Mukhachev, Doctor of Biological Sciences, State Agrarian University of Northern Zauralye, Consultant \\ of TSU, Tyumen, RF, Russia
}

To Cite This Article: IS Mukhachev. Fishing Agricultural Lakes in Zauralia Russia Becomes Progressive. Am J Biomed Sci \& Res. 2019 - 1(5). AJBSR.MS.ID.000541. DOI: 10.34297/AJBSR.2019.01.000541

Received: February 20, 2019 | Published: March 06, 2019

\author{
Abstract \\ Presents examples of the practice of development of commercial lake fish farming on the basis of land reclamation.
}

Keywords: Ecological-Fishery melioration of Lakes; Polyculture, Starlet; Grass carp; White silver carp; Whitefish

\section{Introduction}

Fisheries melioration of lakes in Western Siberia has significant development experience [1-3]. In the modern period, commercial lakes of fish in the Chelyabinsk, Kurgan, Tyumen, Omsk, and Novosibirsk regions on a number of exploited lakes carry out indigenous and current reclamations that contribute to the increase in biological production of water bodies and an increase in commercial fish catch per 1 ha of water area compared to the traditional fishery extensive fish farming technologies. The main thing is that business leaders and leading experts are convinced tangible benefits of land reclamation used and show increased interest and creativity in the development and implementation of scientific recommendations $[4,5]$.

In particular, 2008, specialists of the SRO - Sladkovsky commodity fish farm began in 2008 to restore and modernize the farm, which worked in the 70-80s as part of the Sibrybproma of the Tyumen Region. And literally from "zero" they achieved tangible results, since the entire annual catch of the local fish - gold and silver crucian on 14 thousand hectares of lakes of the chamois type before the organization of the ATRC in 2008 amounted to only 70 tons. In 2017, the total catch of farmed fish (whitefish, carp, pike perch, pike) exceeded 1.3 thousand tons, of which 400 tons were whitefish, 248 tons carp, 131 pike and 31 tons pike. The catch rates of farmed fish by polyculture on some reclaimed small lakes reach $180-250 \mathrm{~kg} /$ ha per year. Very important and with great positive consequences, the workers of the SUC expect from a comprehensive amelioration of the lake.
Tavolzhan (Figure 1), the water area of which together with the island is 10 thousand hectares. In 2008, when we first examined the ecosystem of the lake, the "mirror" of water in the middle of the lake, free from reed beds did not exceed 1-1.2 thousand hectares.

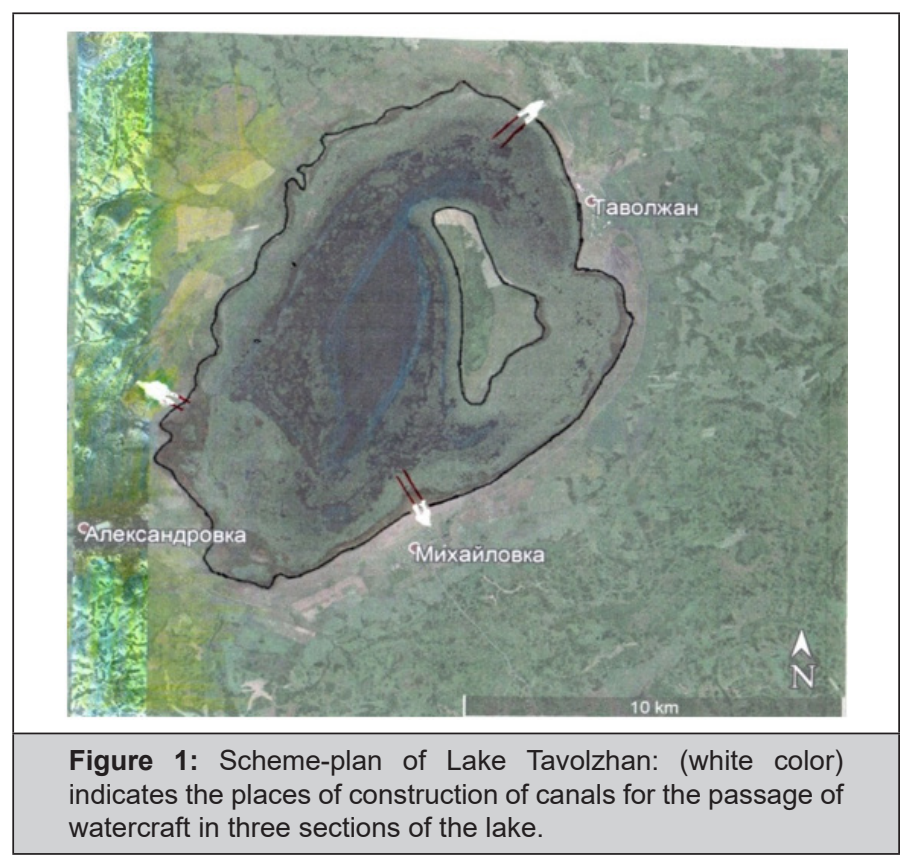

The lake's water in those years was classified by OAAlekina as sodium chloride. total mineralization $11-12 \mathrm{~g} / \mathrm{dm}^{3}$. Formerly, the lake was characterized by "fish-free", since according to the 
information of local residents for the previous 20 years neither gold and silver carp or lake minnow was present. However, 6 years ago, the lake level began to gradually rise annually by $0.1-0.15 \mathrm{~m}$, and the total salinity of water decreased to $7.5-8.0 \mathrm{~g} / \mathrm{dm}^{3}$. This allowed the experts of the SRA to in spring, the introduction of larvae of peled and pelchira (a hybrid of peled and chira) into the open part of the lake, and thanks in advance to dug-out reclaimed canal channels in winter (Figure 2), begin in the second half of summer and in the fall to systematically loosen the bottom sediments of the lake, including the border areas thickets of reeds.

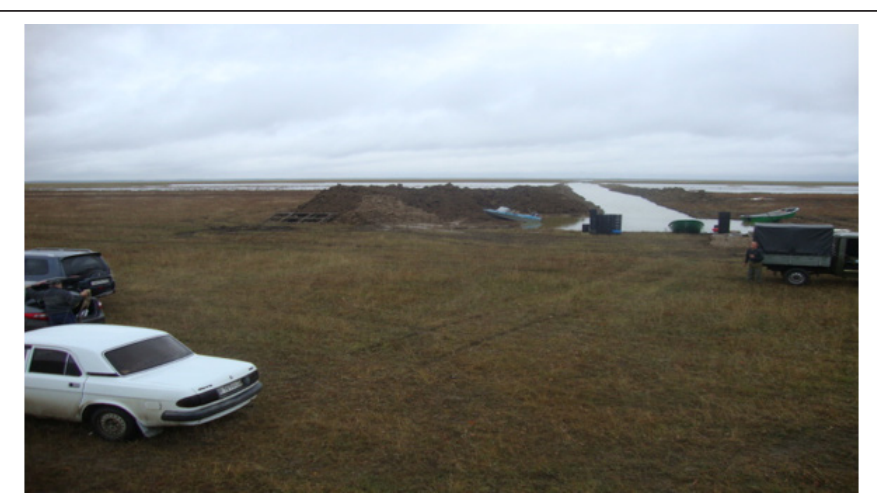

Figure 2: The melioration channel (in open water - for the movement of watercraft; in winter - for the installation of turbo aerators and the capture of whitefish that remain in the process of fishing "in open water".

Due to the movement of the ameliorative silt cultivator not only through the "open" water, but also along the edge of the reed beds, their area began to noticeably decrease as the wind mixing of the water masses and the migration of the "islands" of the reed increased until their complete destruction (Figure 3). In the first year of the production experiment, it was possible to catch 40 tons of commercial yearlings of whitefish weighing $90-120 \mathrm{~g} / \mathrm{pc}$ with the help of fixed two-barrel nets, and in August-September, the fact of "pursuing" a moving boat with bottom sediment ripper by numerous schools of growing young yearlings of whitefish was revealed.

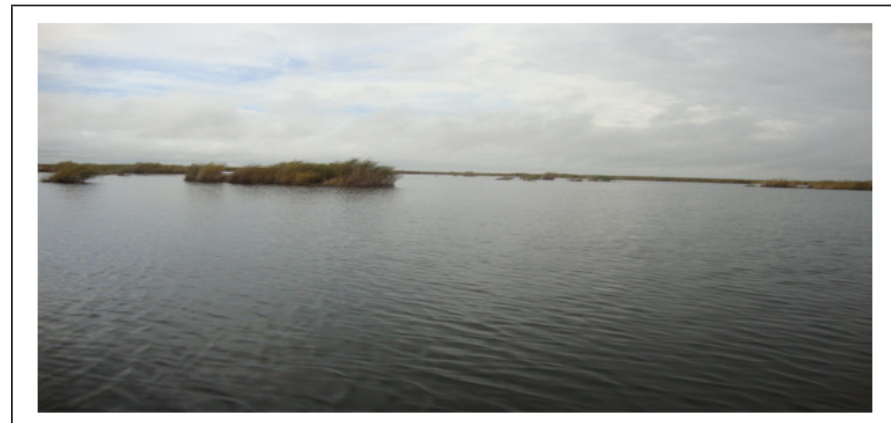

Figure 2: Floating and gradually collapsing reed islets on Lake Tavolzhan (2018).

The fish did not get scared at all by the moving boat with the ripper, because they were attracted by pop-up chironomid larvae, mainly Chironomus plumosus. Similar "ameliorative feeding" of whitefish was also noted on the lakes of other fish farms in the Trans-Urals.
In 2018, the total catch of whitefish in the lake. Tavolzhan amounted to 300 tons, and the water area with sparse thickets of reeds, where whitefish are fed, increased to almost 3 thousand hectares (see Figure 1). In February 2019, thanks to the work of two turbo-aerators with a capacity of $3 \mathrm{~kW}$ each. The craft of peled and pelchira continued. The technical amelioration of the reed thickets in the Sladkovsky fish farm is planned to be combined with the biological amelioration - the introduction of the grass carp yearlings, the production of which is being developed in local fish nurseries.

A similar approach to ameliorative impact is required for the lake ecosystem. Saltaim-Tenis with a water area of 26 thousand hectares, whose water, in contrast to the lake. Tavolzhan is hydrocarbonate-calcium and with a very slow decomposition of dead cane that has fallen to the bottom of the reservoir. Our ecological and fishery monitoring [6-8] has allowed for a long time to justify and suggest that the Krutinsky fish factory and the Omsk Region Administration introduce efficient biological reclamation of the lake based on continuous cultivation as part of productive fish culturegrass carp. This will greatly increase the fish productivity of a large lake [9]. The bioecological essence of introducing white carp into a pasture polyculture is that amur is actively eating young reed plants and other soft vegetation, turning them into recycled plant fiber, which "fertilizes" the lake with organic matter, optimal for the recycling (disposal) of bacteria. Bacteria multiply their abundance, and also contribute to the growth of biomass and production of organisms of zooplankton and zoobenthos, which are the optimal food for fish zooplanktophages and zoophentophages.

We believe that since the need for a biomeliorator - white carp increases in the Trans-Urals and Western Siberia - the construction of the zonal reproduction complex of herbivorous fish should be accelerated. In Petukhov district of the Kurgan region on the lake. Matasi, with a water area of 200 hectares, a production experiment is conducted on the development and sustainable cultivation of whitefish sturgeon polyculture. Lake Matasy with a maximum depth of $3.5 \mathrm{~m}$ represents a typical forest-steppe karasevoy lake with sodium chloride water and a sum of ions of $3-4 \mathrm{~g} / \mathrm{dm}^{3}$.The lake is almost free from hard macrophytes and is characterized by a slight development of soft aquatic vegetation, but with an abundance of gammarus, daphnia magna and other representatives of zooplankton and zoobenthos. Carried out in accordance with zonal bionormativs at the beginning of May 2018, the first introduction of bred fry of sterlet weighing 1.5-2g/pcs. and 3-4-day larvae of peled and its hybrid forms with chir and nelma with high development of the food base showed good results: on October 10-11, the average mass of peled yearlings was $112 \mathrm{~g}$, sigon hybrids $140-150 \mathrm{~g}$, and juvenile sterlet reached a mass of $320-480 \mathrm{~g} / \mathrm{pcs}$.

The control fishing of farmed fish carried out on February 17, 2019 showed that the weight of whitefish approached the average value of $180 \mathrm{~g}$, and sterlet $-50 \mathrm{~g} / \mathrm{pc}$. And all this is due to the high natural forage base of the lake. Farm operating Lake. Matasi, uses mini-turbo aeratoy on the reservoir, and proceeds to work on the creation of a satellite reservoir with nursery ponds using the NP Slinkin technology $[5,10]$, and also provides effective protection 
farmed fish from premature catch. The cultivation of commercial polyculture of fish is planned on the basis of the technology of two years of feeding.

The technology of two-year feeding of whitefish and carp, which was introduced on almost all small lakes of CJSC "Kazan fish" of the Tyumen region, allowed to double the catches compared to the technology of one-year-old commercial fish rearing.

Table 1: Dynamics of commercial fish in the JSC "Kazan fish".

\begin{tabular}{|c|c|c|c|}
\hline \multirow{2}{*}{$\begin{array}{c}\text { Total catch of commercial } \\
\text { fish, } \mathbf{t}\end{array}$} & \multicolumn{3}{|c|}{ Years } \\
\cline { 2 - 4 } & $\mathbf{2 0 1 5}$ & $\mathbf{2 0 1 6}$ & $\mathbf{2 0 1 7}$ \\
\hline Total, t & 555,0 & 1157,0 & 1184,0 \\
\hline including: & & & \\
\hline Whitefish (peled, pelchir) & 151,0 & 659,0 & 556,0 \\
\hline Carp & - & 16,0 & 354,0 \\
\hline Pike & 4,0 & 19,0 & 43,0 \\
\hline Silver carp & 396,0 & 444,0 & 212,0 \\
\hline Perch, roach and other fish & 4,0 & 19,0 & 19,0 \\
\hline
\end{tabular}

An analysis of the work of a number of lake fish farms in the Zauralye shows the real benefits and effectiveness of scientificallydeveloped complex land reclamation of lakes of the observatory type, which in their natural state represent low-productive ichthyocenoses and low fish catches. An increase in the total catch of marketable fish can be achieved through the actual provision of viable planting material to objects from hatcheries directly near intensive feeding farms.

\section{References}

1. Berezovsky AI (1935) Melioration in fisheries. KOIZ p. 76.

2. Folitarek SS (1984) Problems of complex and intensive use of biological resources of lakes in Western Siberia. Biological resources of inland waters of Siberia and the Far East. Nauka, Moscow, p. 33-45.

3. Cherfas BI (1956) Fish farming in natural waters. Pishepromizdat p. 468.

4. Mukhachev IS (2013) Lake commercial fish farming. Lan publishing house, St. Petersburg, p. 400.

5. Slinkin NP (2009) New methods of intensification of lake fishing and fish farming. TGSHA, Tyumen, p. 151.

6. Mukhachev IS, Pivnev IA, Rybkin VP (1974) Development of a biological study increase of fish productivity of lakes Ik and Saltaim-Tenis. Report of SibNIIRH, Tyumen, p. 116.

7. Rybkin VP (1975) Fodder base of lakes Ik and Saltaim-Tenis and its use by fish. Abstracts of reports to the scientific and practical. Conf. SibrybNIIproekt for the development of the Tyumen fisheries complex. Sibryb NIIproekt, Tyumen pp.102-103.

8. Sherenkova IP, Chernukho AA (1967) Lakes of the Krutinsky system of the Omsk region as a base for the organization of highly productive fisheries. Ozernoye and Pond economy in Siberia and the Urals. SibNIIRH, Tyumen pp. 133-140.

9. Mukhachev IS (2018) The substantiation of the industrial pasture technology of growing commercial fish on the ecological and production potential of Saltaim Tenis Lake. International Scientific and Practical conf "Ecological readings-2018". OmGAU, Part 2, pp. 201-214.

10. Bogatov IB (1980) Fish hydrobiology. Food Industry p. 168. 